УДК 78.071.2

DOI https://doi.org/10.31723/2524-0447-2021-32-2-17

\author{
Олександр Сергійович Плохотнюк \\ ORCID: 0000-0003-0444-1615 \\ кандидат педагогічних наук,
}

доцент кафедри музичного мистецтва та хореографії

Навчально-наукового інституту культури і мистецтв

ДЗ «Луганський національний університет імені Тараса Шевченка» alexandr.plokhotnuk@gmail.com

\author{
Дмитро Юрійович Голобородов \\ ORCID: 0000-0001-9744-0026 \\ студент магістратури
}

Навчально-наукового інституту культури і мистецтв ДЗ «Луганський національний університет імені Тараса Шевченка» dmitry.malz@gmail.com

\title{
МУЛЬТИІНСТРУМЕНТАЛІЗМ ЯК ЗАСІБ РОЗВИТКУ ПРОФЕСІЙНИХ УМІНЬ МУЗИКАНТА
}

Мета роботи полягає в дослідженні впливу мультиінструменталізму на розвиток професійних умінь музиканта. Методологія дослідження спирається на загальнонаукові принципи діалектики, термінологічного, системного та комплексного підходів; дослідження явища мультиінструменталізму (В. Білас, С. Королевський, І. Мацієвський та інші). Під час дослідження були використані такі методи: емпіричні (спостереження, порівняння), загальнологічні (аналіз, синтез, абстрагування). Наукова новизна дослідження полягає у виявленні позитивного впливу мультиінструменталізму на розвиток професійних умінь музиканта. Висновки статті дозволяють говорити про мультиінструменталізм як один із засобів розвитку професійних умінь музиканта. Явище володіння грою на двох або більще не близько споріднених інструментах за умов правильного підходу суттєво розширює перспективи індивідуального розвитку музиканта. В умовах жорстокої конкуренції на ринку праці музиканти-мультиінструменталісти почуваються дещо легше й мають більше шансів для самореалізації. У статті розглянуто переваги, якими володіє мультиінструменталіст для працевлаштування. Опанування більшої кількості інструментів дозволяє керівникам ансамблів краще розуміти учасників свого колективу. Мультиінструменталізм надає музикантам низку фінансових та кар'єрних переваг. Позитивний вплив цього явища спостерігається в діяльності викладачів, композиторів і аранжувальників. Вивчення кількох музичних інструментів значно покрашує читку нот з аркуша, розширює світогляд

(С) Плохотнюк О. С., Голобородов Д. Ю., 2021 
музиканта та його музикальність. Мультиінструменталізм є одним із способів подолання депресії в музиканта. Окрім иього, мультиінструменталісти мають низку переваг $і$ під час роботи в умовах дистаниійного режиму. Факт існування мультиінструменталістів-професіоналів, які почуваються впевненіше за мономузикантів у музичному середовищі, дає підстави для грунтовнішого вивчення впливу явища мультиінструменталізму на розвиток професійних умінь музикантів.

Ключові слова: мультиінструменталізм, музиканти-мультиінструменталісти, професійні вміння музиканта.

Plokhotniuk Oleksandr Serhiiovych, Doctor of Pedagogy, Associate Professor at the Department of Music and Choreography of the Educational and Scientific Institute of Culture and Arts, Luhansk Taras Shevchenko National University

Holoborodov Dmytro Yuriiovych, Student Master's Degree of the Educational and Scientific Institute of Culture and Arts, Luhansk Taras Shevchenko National University

Multi-instrumentalism as a means of development the professional skills of a musician

Research objective. The aim of the work is to study the influence of multi-instrumentalism on the development of musician's professional skills. The methodology of the research is based on general scientific principles of dialectics, terminological, systemic and complex approaches; research of the phenomenon of multi-instrumentalism (V. Bilas, S. Korolevsky, I. Matsievsky, etc.). The following methods were used during the study: empirical (observation, comparison), general science (analysis, synthesis, abstraction). The scientific novelty of the research is to identify the positive impact of multi-instrumentalism on the development of musician's professional skills. Conclusions. The conclusions of the article allow us to talk about multi-instrumentalism as one of the means of developing the musician's professional skills. The phenomenon of mastering two or more not closely similarity instruments with the right approach significantly expands the prospects for individual development of the musician. In the conditions of fierce competition in the labor market, musicians-multiinstrumentalists feel a little easier and have more chances for self-realization. The article considers the advantages that multi-instrumentalism provides to musicians during employment. Mastering more instruments allows ensemble leaders to better understand the musicians of their band. Multi-instrumentalism gives musicians a number of financial and career benefits. The positive influence of this phenomenon is observed in the activities of teachers, composers and arrangers. The study of several musical instruments significantly improves sightreading, expands the worldview of the musician and his musicality. Multiinstrumentalism is one of the ways to overcome depression in a musician. In addition, multi-instrumentalists have a number of advantages when working in remote mode. The fact of the existence of multi-instrumentalists-professionals, who feel more confident than mono-musicians in the music environment, gives grounds for a more thorough study of the impact of the multi-instrumentalism's phenomenon on the development musicians' professional skills.

Key words: multi-instrumentalism, musicians-multi-instrumentalists, professional skills of musician. 
Актуальність теми дослідження. Поява на початку XXI ст. музичному мистецтві значної кількости виконавців на кількох музичних інструментах привела до необхідності грунтовнішого вивчення явища мультиінструменталізму. Питання про позитивний вплив мультиінструменталізму на музикантів порушували у своїх статтях Ф. Нільсен, Р. Фрейтас, Д. Саммер. Вплив мультиінструменталізму на формування та розвиток професійних умінь львівських музикантів-духовиків досліджував В. Білас [1]. Про важливість уміння грати на різних музичних інструментах для майбутнього вчителя музики писав С. Королевський [3]. Незважаючи на наявність низки робіт із дослідження цього феномену, актуальним залишається питання вивчення впливу мультиінструменталізму на розвиток професійних умінь музиканта.

Мета дослідження полягає в тому, щоб дослідити вплив мультиінструменталізму на розвиток професійних умінь музиканта.

Наукова новизна дослідження полягає у виявленні позитивного впливу мультиінструменталізму на розвиток професійних умінь музиканта.

Виклад основного матеріалу. Для успішної професійної діяльности музикант повинен володіти такими якостями та здібностями, як: музичні здібності (гарний музичний слух, музична пам'ять, почуття ритму), добре розвинута моторна пам'ять (м'язова пам'ять на типи рухів), креативність, творчість, швидкість реакції, розвиток дрібної моторики рук (гнучкість, чіткість рухів кистей рук і пальців), здатність до імпровізації, артистичні здібності, терплячість, наполегливість, цілеспрямованість, оригінальність, інтуїтивність, емоційний інтелект, прагнення до самовдосконалення, комунікативні та адаптивні якості. Наявність певних якостей музиканта проявляється в його професійних уміннях: грати перед публікою, читати ноти з аркуша, грати гуртом, створювати музику, виконавські вміння, уміння супроводжувати соліста та створення музичного супроводу для нього, уміння адаптуватися в незвичних умовах, педагогічні уміння тощо. Музиканти мають багато можливостей для прояву своїх професійних умінь, наприклад: виступ у ролі соліста-виконавця, робота в оркестрі під керівництвом диригента, акомпанування, запис музичного супроводу солісту-виконавцю або колективу, викладання (педагогічна діяльність), керівництво 
(диригування) іншими виконавцями чи цілим оркестром, участь у постановці та реалізації концертних програм, композиторська діяльність тощо [5].

Відповідно до вищезазначеного, розглянемо, чи сприяє мультиінструменталізм розвиткові професійних умінь музиканта.

Музиканти, які грають на кількох інструментах, ставлять перед собою набагато більше складних завдань, ніж моноінструменталісти. Дуже часто розв'язання більшої кількості завдань дозволяє мультиінструменталістам краще адаптуватися на сучасному ринку праці. Подолання труднощів сприяє самореалізації музиканта, яка своєчергово приводить до відчуття щастя та покращує загальний настрій. Людина, що змогла реалізуватися, почувається оптимістично. Оптимізм - це ставлення людини до життя, яке не дозволяє їй опустити руки або впасти в депресію під тиском скрутних обставин. Оптимізм є прогностичним чинником успішности в навчанні [2, с. 167]. Отже, маючи більше шансів для самореалізації, мультиінструменталісти частіше переживають стан натхнення, який спонукає їх до вдосконалення своїх професійних навичок (рис. 1).

\section{Самореалізація}

\section{Відчуття щастя}

\section{Натхнення}

(стам пінесеми тиориих си,

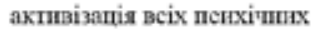
mpotrecis moдини)

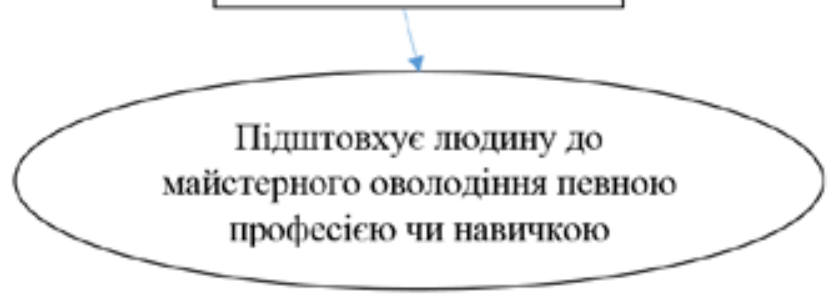

Рис. 1. Вплив натхнення на розвиток професійних навичок за Д. Гоулманом 
Експериментально доведено, що справжніми професіоналами в мистецьких професіях стають лише ті студенти, які отримували справжню насолоду від процесу навчання своїй майбутній професії. Студенти ж, які мріяли лише про славу та багатство, здебільшого кидають мистецьку діяльність після закінчення навчання. Для музиканта натхнення теж є необхідною умовою для засвоєння знань та вдосконалення своїх професійних якостей. Студенти, які відчувають натхнення у процесі навчання, стають успішними [2, с. $175-176]$.

Одночасне вивчення кількох інструментів вимагає від музиканта більшого часу для занять, отже, розвиває терплячість, наполегливість, цілеспрямованість, прагнення до самовдосконалення. Швидке перелаштування 3 одного інструмента на інший потребує від музиканта величезної концентрації й уваги, сприяє розвиткові дрібної моторики рук, інтонації, музичної пам'яті, уваги, слуху, ритму, м'язової пам'яті, креативности, творчости, швидкости реакції, значно покращує читку з аркуша. Усі перелічені якості розвивають у музиканта вміння адаптуватися в незвичних умовах (рис. 2).

Активізація концертної діяльности сприяє розвиткові пам'яті та стійкості уваги, допомагає подолати відчуття страху та боязливості сцени. Оскільки мультиінструменталізм надає можливість музиканту мати більшу кількість публічних виступів, то можна стверджувати, що музиканти-мультиінструменталісти краще переносять стреси, ніж ті, хто грає лише на одному музичному інструменті. Краща переносимість стресу сприяє розвиткові артистичних здібностей, виконавських умінь та вміння грати перед публікою.

Співпраця з більшою кількістю людей, можливість працювати в більшій кількості музичних колективів розвиває соціальну активність, підвищує емоційний інтелект музиканта і також розвиває вміння грати перед публікою (рис. 2).

3 вищесказаного висновуємо, що за умов правильного підходу мультиінструменталізм суттєво покращує адаптивні, комунікативні якості музиканта та низку музичних здібностей. Наявність цих якостей дозволяє музикантам-мультиінструменталістам легше реалізовувати свої професійні вміння в умовах жорстокої конкуренції на ринку праці. 


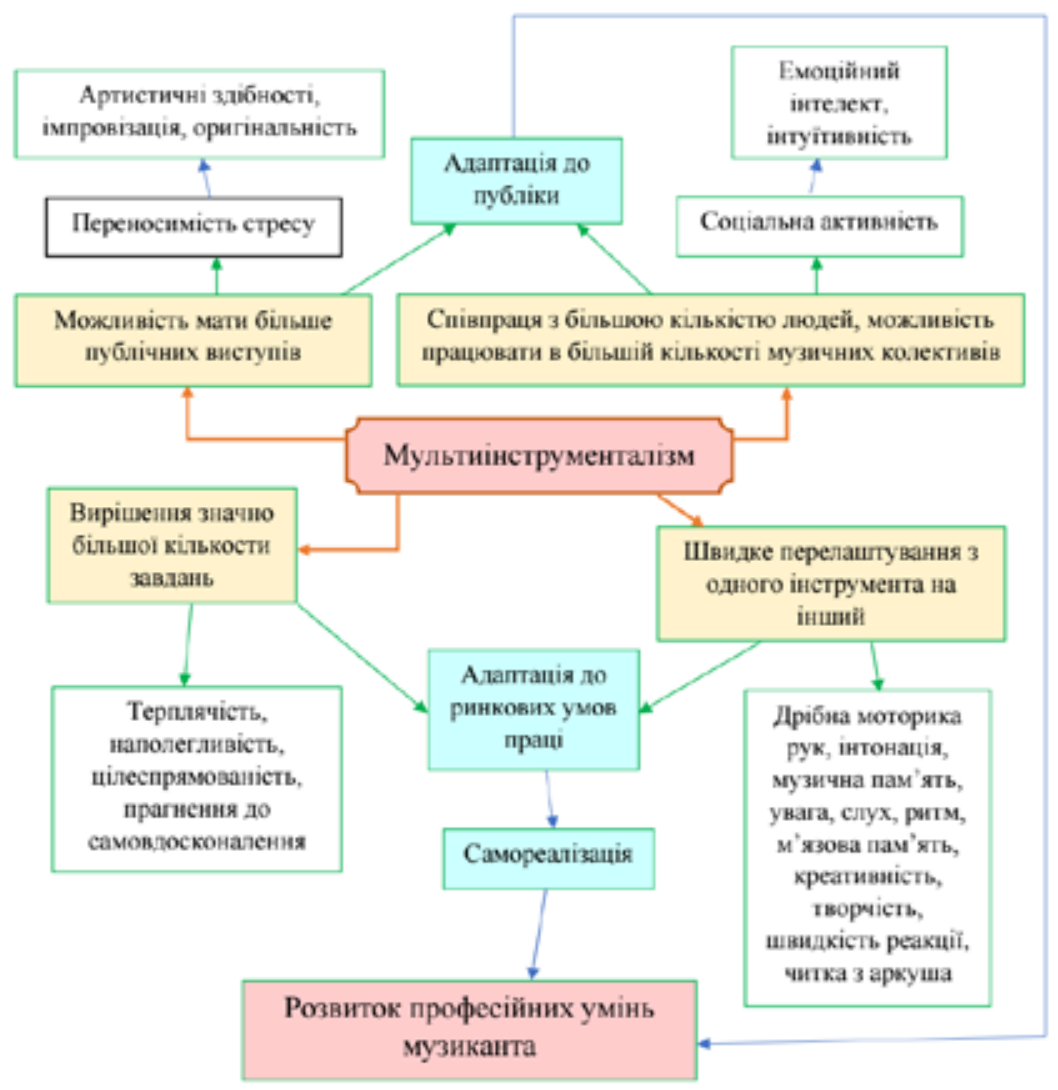

Рис. 2. Вплив мультиінструменталізму на розвиток якостей та професійних умінь музиканта

Надалі з'ясуємо, які переваги може надавати мультиінструменталізм музикантам у виконавському процесі.

1. Для інструменталістів, які прагнуть бути в майбутньому диригентами оркестрів, практичне розуміння звуковидобування й особливостей гри принаймні одного інструмента 3 кожної інструментальної родини (струнно-смичкові, мідні духові тощо) є невід'ємною частиною їхньої професійної кар'єри та продуктивної співпраці з музикантами. Теоретичне розуміння гри, безперечно, теж важливе, проте воно не може повноцінно замінити досвід гри. Отже, кращими 
керівниками гуртів та диригентами оркестрів $є$ ті, хто освоїв декілька різних музичних інструментів. Опанування більшої кількости інструментів дозволяє ліпше розуміти музикантів свого ансамблю, знати роль кожного інструмента в музичному колективі. Диригент-мультиінструменталіст може допомогти музикантам свого оркестру подолати деякі труднощі, показати їм кілька виконавських прийомів, які б допомогли під час виконання творів [9]. І. Мацієвський зазначав: «Володіння кількома музичними інструментами - мультиінструменталізм - необхідна якість для керівника ансамблю» [4, с. 191]. Мистецтвознавець підкреслював, що знання та виконавська майстерність у професіонала тісно переплетені. Найскладніші місця у творі доручаються лідерові ансамблю. Він перевіряє настроювання всіх інструментів, стежить за грою членів ансамблю, є водночас і художнім керівником, і провідним виконавцем. У традиційному ансамблі керівником не може бути другорядний спеціаліст, інакше колектив не протримається довго [4, с. 192-193].

2. Мультиінструменталізм надає фінансові та кар'єрні переваги. По-перше, мультиінструменталістам легше влаштуватися на роботу водночас у кілька музичних колективів. У кількох колективах в один момент часу можуть бути доступні вакансії для різних інструментів. Наприклад, у ситуації, коли в симфонічний оркестр потрібен кларнетист, а в камерний - альтист, професійний альтово-кларнетовий дублер має змогу подати заявку одночасно на прослуховування в обидва колективи, таким чином шанс улаштуватися на роботу в такого музиканта удвічі вищий за його конкурентів-моноінструменталістів.

По-друге, є працевлаштування в оркестрах, які потребують наявности у своєму складі саме дублерів. До таких колективів належать, наприклад, піт-оркестри, де мультиінструменталісти з різних причин економічно вигідніші роботодавцям. У країнах першого світу (США тощо) зазвичай таким гравцям виплачується доплата за кожен додатковий інструмент [6, c. 9].

3. На сеансах звукозапису перевага іноді віддається теж мультиінструменталістам. Якщо, наприклад, співаку потрібно записати супровід до пісні у студії, йому зручніше й економічно вигідніше найняти одного професійного музиканта-мультиінструменталіста, який зможе зіграти партії кількох різних інструментів [7]. 
4. $\boldsymbol{У}$ педагогіиній діяльності в музиканта-викладача, який уміє грати на багатьох інструментах, очевидно, буде більще учнів, отже, й дещо вищий заробіток. Окрім авдиторних уроків з учнями, нерідко вчителі-дублери практикують поширення своїх знань і за допомогою сайтів у Всесвітній мережі - вони створюють різноманітні цікаві, як безкоштовні, так і платні, онлайн-курси з уроками музики [8]. Педагог-мультиінструменталіст може зацікавити учня різними музичними інструментами й у підсумку вибрати саме той, який найбільше сподобався вихованцю. Наявність педагогів-мультиінструменталістів розкриває широкі перспективи в музичному навчанні дітей у новій українській школі.

5. Володіння грою на кількох музичних інструментах також вигідно для композиторів $і$ для аранжувальників. Якщо композитор уміє грати на багатьох інструментах із різних родин і хоче записати власний твір, він може заощадити гроші, як мінімум зіграти деякі партії твору самостійно (без запрошення декотрих музикантів), або, як максимум, виконати самотужки запис усієї композиції (звісно, якщо він володіє всіма необхідними для запису твору інструментами). У виробленні сучасної музичної продукції й авдіоінженерії освоєння більше ніж одного інструмента є дуже цінним явищем.

6. Вивчення другого, третього чи четвертого інструмента - це один із засобів розширення своєї музикальності та cвimогляду. Можливо, музикант не стане в майбутньому віртуозом у грі на конкретних інструментах, але знання більш аніж одного інструмента принесе користь усім аспектам його музичної практики: власному написанню пісень, розумінню теорії, слуховим навичкам і вмінню грати в колективі. Незалежно від того, на якому рівні музикант опанує додатковий інструмент, він зможе збільшити свою здатність до створення музики. Завдяки комбінуванню набутих під час вивчення музичних інструментів знань людина отримує новий погляд на творення музики.

7. Мультиінструменталізм може бути одним зі способів подолання депресії. Подібно до того, як щоденна восьмигодинна праця із часом стає нудною, музичний інструмент, через безперервне вправляння протягом тривалого періоду, теж може набриднути. У такі дні робота з інструментом перестає бути творчістю, цікавість та запал згасають, як наслідок інструмент може погано звучати, пальці втрачають активність, 
не слухаються тощо. У таких ситуаціях відволікання від свого інструмента на деякий час корисне. Прекрасною можливістю переключити увагу, залишаючи себе в музичній сфері, є гра на іншому музичному інструменті. Наприклад, процес вивчення складної п'єси можна продовжувати й на іншому інструменті - фразування, мелізми, динаміку, запам'ятовування нотного тексту тощо. Така кількаденна зміна діяльности освіжить музиканта, він зможе повернутися до інструмента, від якого напередодні «отримав перенасичення», 3 новими силами та захопленням. Відомий американський психолог Деніел Гоулман писав, що відволікання - це спосіб подолати легку депресію та позбутися поганого настрою загалом [2, с. 143]. Отже, явище мультиінструменталізму допомагає музикантам підтримувати свій загальний настрій, який $€$ невід'ємною складовою частиною високого емоційного інтелекту, а також уміло застосовувати свої професійні якості в будь-яких ситуаціях.

8. Одним із важливих умінь для становлення музичних виконавців є читка з аркуша (далі - ЧА). Це - навичка музиканта відтворювати записаний у музичній нотації твір без попереднього вивчення. Вона є необхідною складовою частиною професійного зростання музиканта. Безперечно, вивчення нових музичних інструментів є одним зі способів покращення ЧА. Музикант, коли вивчає різні інструменти, отримує ширшу та різноманітнішу як теоретичну підготовку, так і виконавську практику. Прикладом розширення першої $\epsilon$ накопичення музикантом більшої кількости теоретичних знань, зокрема термінологічного словника. Так, звичний для оркестрових гравців на мідних духових інструментах термін "tacet" для скрипалів часто не є відомий через малу кількість його вживання у скрипковій нотній літературі. Прикладом неочікуваного скрипкового тасету є партія другої скрипки квартету № 6 Й. Гайдна (опус 20).

Розглянемо практичну складову частину, яка впливає на підвищення читки з аркуша внаслідок гри на кількох інструментах. По-перше, як раніше зазначалося, володіння грою на більшій кількості інструментів дає можливість долучитися до більшої кількости колективів. Тобто людина-мультиінструменталіст загалом має більше гуртової практики, яка не лише спонукає до відповідальности перед колективом, а й впливає на розвиток ЧА й інтенсивність професійного росту гравця. 
По-друге, кожен інструмент має свої складнощі та технічні обмеження, особливості тембрів тощо, а отже, і функції в ансамблях. Через це наповнення нотного тексту, особливо оркестрових партій, від інструмента до інструмента дещо відрізняється. Так, наприклад, більшість зразків симфонічно-оркестрових партій труби не вміщують ритмічно складні пасажі, через це безпосередня гра в оркестрі (якщо брати іiі до уваги ізольовано від інших видів діяльності музиканта домашньої практики тощо) не дозволяє трубачам закріпити на належному рівні гру подібних місць до рівня гарної читки 3 аркуша. Якщо ж трубач володіє інструментом, у партіях якого подібні ритмічні пасажі є часто вживані (напр., флейта, скрипка тощо), і в нього розвинута гарна ЧА подібних ритмічних структур на цьому інструменті, очевидно, що він відчуватиме менший дискомфорт у разі їх появи в партії труби. Такий мультиінструменталіст принаймні буде більше підготований до сприймання неочікуваних місць у творах. Звісно, варто зауважити, що ця прогалина може бути усунута наднормовою кропіткою самостійною працею музиканта.

9. Розвиток більшої кількости м'язів тіла. Усі музичні інструменти для видобування на них якісного та професійного звуку від людського тіла вимагають різних фізичних / рухових навичок, які розвиваються у процесі вивчення музичного інструмента. Тобто опанування гри будь-якого інструмента людиною супроводжується зміцненням конкретних іiі м'язів та набуттям уміння досконало й мимовільно керувати ними. Так, наприклад:

- гра на ударній установці допомагає музикантові навчитися виконувати асинхронні дії всіма своїми кінцівками водночас;

- гра на саксофоні, скрипці, акордеоні тощо допомагає зміцнити м'язи пальців рук, покращити їхню моторику;

- гра на будь-якому духовому інструменті розвиває м'язи грудної клітки та черевного пресу (включно з м'язами діафрагми).

Музикант, який вправляється безустанно на будь-яких кількох інструментах, тренує й більшу кількість м'язів тіла. Варто зазначити, що одночасне вивчення деяких конкретних інструментів особливо корисне для гравців. Це, зокрема, стосується тих випадків, коли інструменти, що вивчаються музикантом, потребують для звуковидобування задіяння подібного 
набору м'язів, але через деякі причини з різною інтенсивністю розвивають їх. Прикладом такої пари інструментів є тромбон та труба. Вивчення гри на тромбоні корисно для трубача. Більший діаметр тромбонового мундштука дозволяє розвити менше задіяні у грі на трубі м'язи лиця, тим самим загально зміцнити амбушюр трубача.

10. Мультиінструменталізм надає переваги музикантам i під час роботи в умовах дистанційного режиму. Трапляються ситуації в житті, коли музиканти вимушені вирішувати робочі моменти зі своїми колегами-інструменталістами дистанційно. Причиною неможливости співпрацювати наживо можуть бути, наприклад, карантинно-санітарні заходи на визначених територіях, які обмежують вільне пересування людей. Робота в умовах дистанційного режиму нерідко ставить перед багатьма музикантами низку викликів. Виконавці, що грають на кількох інструментах, мають більше засобів для швидкого їх вирішення. Так, наприклад, однією з поширених проблем є складність звукозапису музичного супроводу для виконання своєї робочої п'єси. Професійний мультиінструменталіст (на противагу моногравцеві) може самостійно записати для себе мінус, поєднавши звучання музичних інструментів, на яких він уміє грати, і успішно скласти екзамени зі спеціального інструменту, ансамблевого класу тощо.

Також окрім переваг у виконавській, викладацькій діяльності та роботі у студіях звукозапису професійні мультиінструменталісти затребувані під час прийому на роботу на такі посади, як музичний журналіст, звукорежисер, технік із ремонту музичних інструментів, музичний терапевт і етномузиколог [10].

Наприклад, етномузикологи досліджують культуру різних народів та країн. Більшість із них підбирає музичні інструменти, які є рідними для країни, яку вони вивчають, освоюють ці етнічні інструменти, щоб надалі зануритись у культуру. Отже, дуже часто етномузикологи є надзвичайно талановитими мультиінструменталістами [10].

Висновки. У процесі дослідження виявлено, що мультиінструменталізм сприяє розвиткові професійних умінь музиканта, як-от: уміння грати перед публікою, адаптуватися в незвичних умовах, композиторські вміння, уміння читати ноти 3 аркуша, супроводжувати соліста тощо. 
Розглянуто низку переваг, які надає музикантам мультиінструменталізм під час працевлаштування. 3'ясовано, що вміння грати на кількох інструментах допомагає диригентам, розвиває композиторські навики, надає фінансові та кар'єрні переваги, розширює музикальність, допомагає уникати стресів і депресій, надає переваги під час роботи в умовах дистанційного режиму тощо. Наявність у музиканта гарних виконавських навичок гри на багатьох музичних інструментах - це запорука його багатосторонньої та високоякісної музичної творчости. Отже, ми з'ясували, що мультиінструменталізм позитивно впливає на розвиток професійних умінь музиканта.

Перспективи цього дослідження полягають у пошуку імен виконавців-мультиінструменталістів та вивченні впливу явища мультиінструменталізму на розвиток професійних якостей музикантів.

\section{СПИСОК ЛІТЕРАТУРИ}

1. Білас В. Явище мультиінструменталізму у творчості львівських виконавців-духовиків. Історія становлення та перспективи розвитку духової музики в контексті національної культури України та зарубіжжжя : збірник наукових праць. Рівне : Волинські обереги, 2017. Вип. 9. С. 187-191.

2. Гоулман Д. Емоційний інтелект. Харків : Віват, 2019. 512 с.

3. Королевський С. Формування професійної компетентності майбутнього вчителя музики в процесі оволодіння різними видами музичних інструментів, 2019. URL: https://vseosvita.ua/library/stattaformuvanna-profesijnoi-kompetentnosti-majbutnogo-vcitela-muziki-vprocesi-ovolodinna-riznimi-vidami-muzicnih-instrumentiv-118995.html (дата звернення: 30.04.2021).

4. Мациевский И. Народная инструментальная музыка как феномен культуры. Алматы : Дайк-Пресс, 2007. 520 с.

5. Australian Bureau of Statistics. ANZSCO - Australian and New Zealand Standard Classification of Occupations, Version 1.3, 2019. URL: https://www.abs.gov.au/ausstats/abs@.nsf/Latestproducts/10EF3C2AAC17C386CA2584A8000E7A25?opendocument (дата звернення: 11.05.2021).

6. Boulder Philharmonic orchestra. Master agreement 2019-2022. Boulder, 2019. $51 \mathrm{p}$.

7. Doubler David Summer, 2021. URL: https://www.summersong.net/ music-education-resources/instrumental-doubling/ (дата звернення: 30.04.2021).

8. Freitas R. 5 benefits and 5 problems of playing multiple musical instruments by Ryan Freitas. 2016. URL: https://www.vibemusicacademy.com/ blog/2016/5/17 (дата звернення: 30.04.2021). 
9. Nielsen F. The Pros and Cons of Being a Multi-Instrumentalist, 2019. URL: https://www.roadietuner.com/blog/the-pros-and-cons-of-being-a-multi-instrumentalist/ (дата звернення: 30.04.2021).

10. Welsh D. 4 of the Most Overlooked Paths to a Career in Music. 2015. URL: https://blog.sonicbids.com/4-of-the-most-overlooked-pathsto-a-career-in-music (дата звернення: 30.04.2021).

\section{REFERENCES}

1. Bilas V. (2017) Yavyshche multyinstrumentalizmu u tvorchosti lvivskykh vykonavtsiv-dukhovykiv [The phenomenon of multi-instrumentalism in the work of Lviv wind performers]. History of formation and prospects of development of wind music in the context of national culture of Ukraine and abroad, vol. 9, pp. 187-191. [in Ukrainian].

2. Goulman D. (2019) Emotsiinyi intelekt [Emotional intelligence]. Kharkiv : Vivat. [in Ukrainian].

3. Korolevskyi S. (2019) Formuvannia profesiinoi kompetentnosti maibutnoho vchytelia muzyky $\mathrm{v}$ protsesi ovolodinnia riznymy vydamy muzychnykh instrumentiv [Formation of professional competence of the future music teacher in the process of mastering different types of musical instruments]. URL: https://vseosvita.ua/library/statta-formuvanna-profesijnoi-kompetentnosti-majbutnogo-vcitela-muziki-v-procesi-ovolodinna-riznimi-vidami-muzicnih-instrumentiv-118995.html [in Ukrainian].

4. Matsievskiy I. (2007) Narodnaya instrumental'naya muzyka kak fenomen kul'tury [Folk instrumental music as a cultural phenomenon]. Almaty : Daik-Press. [in Russian].

5. Australian Bureau of Statistics (2019) ANZSCO - Australian and New Zealand Standard Classification of Occupations, Version 1.3. URL: https://www.abs.gov.au/ausstats/abs@.nsf/Latestproducts/10EF3C2AAC17C386CA2584A8000E7A25?opendocument [in English].

6. Boulder Philharmonic orchestra (2019) Master agreement 2019-2022, Boulder, Boulder Philharmonic orchestra. [in English].

7. Doubler David Summer (2021). URL: https://www.summersong. net/music-education-resources/instrumental-doubling/ [in English].

8. Freitas R. (2016) 5 benefits and 5 problems of playing multiple musical instruments by Ryan Freitas. URL: https:// www.vibemusicacademy.com/blog/2016/5/17 [in English].

9. Nielsen F. (2019) The Pros and Cons of Being a Multi-Instrumentalist. URL: https://www.roadietuner.com/blog/the-pros-and-cons-of-being-a-multi-instrumentalist/ [in English].

10. Welsh D. (2015) 4 of the Most Overlooked Paths to a Career in Music. URL: https://blog.sonicbids.com/4-of-the-most-overlookedpaths-to-a-career-in-music [in English] 